\title{
Education Policy and Practice on Intimate Partner Violence Among Young People in the UK
}

\author{
Xiaomin Sheng \\ University of Huddersfield, the UK
}

\section{Abstract}

This paper presents a qualitative systematic review of educational policy and practice on tackling intimate partner violence (IPV) among young people in the UK. Up to date, the majority of school-based IPV interventions were conducted in the US and now there is growing consensus among UK policymakers, researchers and practitioners as well to address IPV issues through educational practice. This review aims at gathering evidence of the type and nature of policies and institutional level practice adopted to tackle IPV issues among young people within an educational context, and what impacts these interventions have on mitigating the occurrence of IPV. In undertaking this review, three databases (Eric, BEI and Scopus) were searched and grey literature was manually added. Findings from the review suggest that the majority of interventions were effective in altering attitude and promoting awareness of IPV. Still, longitudinal studies are needed to see if changes in attitude can be translated into the effective behavioural alteration in real-life situation. Although most students expressed satisfaction toward the existing interventions, it was also found that lack of consideration of gender can lead to uncomfortable feelings among students. There were contradictory views regarding whether teachers or external experts would be a better person to deliver the intervention and who was the person students preferred to turn to for help. Besides, country-wide interventions are needed to make sure all schools have an opportunity to provide IPV education, and the support from the UK government is of crucial importance to make this happen.

Keywords: intimate partner violence, policy, intervention, education, UK

\section{Introduction}

\subsection{Policy background}

UK policymakers started to put more emphasis on addressing intimate partner violence (IPV) issues since the 1970s, while at that time, IPV came under the umbrella of domestic violence (Gelles, 1980; Graca, 2017). The first attempt of the UK government to fight against domestic violence by law is the enactment of 
Domestic Violence Matrimonial Proceedings Act 1976, which can be regarded as a turning point in the history of UK legislation on addressing domestic violence (Graca, 2017). This act clarifies the equal rights of spouses in a variety of cases and provides the police with the power to handle violence in domestic settings (Graca, 2017). However, in the 1980s and 1990s, IPV preventive works remained low profile in the UK government documents (Coy \& Garner, 2012; Fancy \& Fraser, 2014; Phipps \& Smith, 2012). Then, in the 2000s, more laws, published to address a broader range of IPV issues such as Female Genital Mutilation Act 2003 and Sexual Offences Act 2003, especially the enactment of the Domestic Violence, Crime and Victims (DVCV) Act 2004. DVCV Act (2004) brought numerous changes in respect of criminal law on domestic violence, and have been described as the most significant overhaul of the law relating to domestic violence in the last 30 years (Graca, 2017). After that, The Home Office (2011) implemented Domestic Violence Protection Notices and Orders, which were aimed at providing victims with timely protection and insulating them from abusers' persecution (Graca, 2017). However, up to that point, the majority of the published laws on domestic violence focused on abuse in marital relationships and children maltreatment within the family context, and only limited attention was paid to the prevalence of IPV that occurred among intimate relationships of people young. This situation started to change in 2013, when the UK policy definition of domestic violence was extended to include 16-17 years' old young people due to the increased prevalence of IPV issues among them (Home Office, 2013). The government also issued policy documents such as the Call to End Violence against Women and Girls (EVWG) 2010 and Ending Violence against Women and Girls (EVWG) Strategy 2016-2020 and successfully ran Teenage Relationship Abuse Campaign, all which showed that the UK policy began to make an effort on tackling IPV among young people.

There is an advocacy of the multi-agency approach by the UK government in preventing domestic violence since the 1990s, especially with the implementation of Inter-Agency Circular on Domestic Violence by the Home Office in 1995 (Cleaver, Maras, Oram, \& McCallum, 2019; Graca, 2017). This approach allows different institutions to work collaboratively to provide victims of domestic violence with multiple needs and seamless responses (Graca, 2017). The multi-agency approach was strengthened after the publication of DVCV Act 2004, which required the creation of a variety of institutions to address domestic violence, such as MultiAgency Safeguarding Hubs, Multi-Agency Risk Assessment Conferences and Domestic Violence Courts (Cleaver et al., 2019; Graca, 2017). However, the school's role in domestic violence prevention was less valued by the multi-agency approach, and more emphasis was given to charity organisations, e.g., Tender, Women Aid and NSPCC, especially in providing support to victims of domestic violence (Cleaver et al., 2019; Stanley, Ellis, Farrelly, Hollinghurst, Bailey, et al., 2015). The multi-agency approach is continuing to be used today while there is an increasing recognition of the school's critical position in primary prevention to challenge deep-rooted gender 
norms, inequality and stereotypes among young people. In EVWG Strategy 20162020 , the Home Office proposed a plan to address violence against women and girls, which stresses more the educational function in early IPV intervention than previous government documents. This strategy highlights the partnership with Personal, Social and Health Education (PSHE) Association, headteachers and other practitioners to ensure schools' effectiveness in delivering high quality healthy relationship education in classroom settings (Home Office, 2016, p. 16). In 2018, the Department for Education (DfE) published the draft of Relationship Education, RSE and Health Education Guidance (2019) for consultation. In the draft version of Relationship Education, RSE and Health Education Guidance (2019), general forms of IPV, cyber or sext violence, healthy and safe relationships have been added and advised to be taught in all schools including maintained, non-maintained or independent schools (Department for Education, 2018, 2019). Therefore, it is expected that IPV issues can be statutorily embedded within school curriculum soon in the UK.

\subsection{Research background and questions}

IPV among young people has long been a worldwide concern for policymakers, practitioners and researchers due to its increased visibility in the society, however, it hasn't provoked the same level of interest in the UK as elsewhere (Barter, McCarry, Berridge, \& Evans, 2009; Young et al., 2017). In contrast, the US currently has the majority of research evidence on IPV (Bell \& Stanley, 2006; Parkes, Heslop, Ross, Westerveld, \& Unterhalter, 2016; Stanley, Ellis, Farrelly, Hollinghurst, Bailey, et al., 2015). While British young people experience the similar level of risk of sexual abuse with their peers in the US, much fewer interventions have been developed to combat the issues in the UK (Phipps \& Smith, 2012). Several systematic review studies have been undertaken to inform the UK policy and practice on IPV prevention by reviewing interventions outside of the UK context (Bell \& Stanley, 2006; Khadijah \& McAslan, 2014; Stanley, Ellis, Farrelly, Hollinghurst, Bailey, et al., 2015), whereas, very few systematic reviews can be identified to collect the evidence to evaluate the intervention of IPV that is solely to do with the UK context. It is doubtful if the findings from the intervention outside of the UK context are applicable within the UK context since IPV is a complex issue and involves deeprooted cultural norms, rituals and customs passed between generations. To establish the evidence for educational policy and practice on addressing IPV among young people in the UK, and to provide implications for policy development and further research, this qualitative systematic review sought answers regarding the following questions:

In what ways have policies and institutional level practices been used, or can be used, as a tool or mechanism for tackling IPV in different educational contexts in the UK? 
What impacts have these educational policies and practices had on addressing IPV and what evidence exists to support this?

\subsection{The current study}

This review identified three systematic reviews aimed at recognising IPV related interventions in the UK. However, all the identified systematic reviews attempt to inform the UK based practice primarily by examining interventions undertaken outside of the UK context (Stanley, Ellis, Farrelly, Hollinghurst, Bailey, et al., 2015; Stanley, Ellis, Farrelly, Hollinghurst, \& Downe, 2015), analysing reports from the UK grey literature (Stanley, Ellis, Farrelly, Hollinghurst, Bailey, et al., 2015) or drawing on IPV related research evidence out of the educational setting (Cleaver et al., 2019). None of these reviews has evaluated the evidence on the effectiveness of educational policy and home-grown intervention specifically within educational settings in the UK (Stanley, Ellis, Farrelly, Hollinghurst, Bailey, et al., 2015). Therefore, this qualitative systematic review will narrow this research gap and promote future knowledge development in this field.

\section{Review framework and methodological approach}

\subsection{Literature identification}

We undertook a qualitative systematic review of IPV educational policy and practice from 1990, when the works in the field of IPV started to increase in the UK, to March 2019. A search was performed in three bibliographic databases: Education Resources Information Centre (ERIC), British Education Index (BEI) and Scopus. To identify relevant literature in these three bibliographic databases, we performed PICo (population, phenomenon of interest and context) as the searching framework (See Appendix A) with the combination of Boolean phrases (See Appendix B). The bibliographic searches included 1,161 articles, the majority of the papers identified for this research are from peer-reviewed journals. Avoid missing out relevant publications, a complementary search by manually scanning the citations in included articles was adopted, which added eight papers into this review. Finally, 11 published studies have been included in this review (see in Fig.1).

\subsection{Literature screen}

In the process of literature screen, the included 11 papers followed a detailed inclusion and exclusion criteria (see in Table 1). This inclusion and exclusion criteria has been applied to exclude studies regarding title and keywords, abstract, full-text and a process of detailed review.

\subsection{Data extraction and results}

\subsubsection{Data extraction}

To address the review questions mentioned in Section 1.2, 11 included articles were extracted into a summary table (see in Table 2). Detailed information was retrieved 
from 11 studies to answer two review questions as: name, type, location of intervention; author, publicantion year, type of paper; details of intervention; mentioned UK policy or intervention; and summary of the findings, as summarised in Table 2.

Fig. 1. Flow chart of included studies

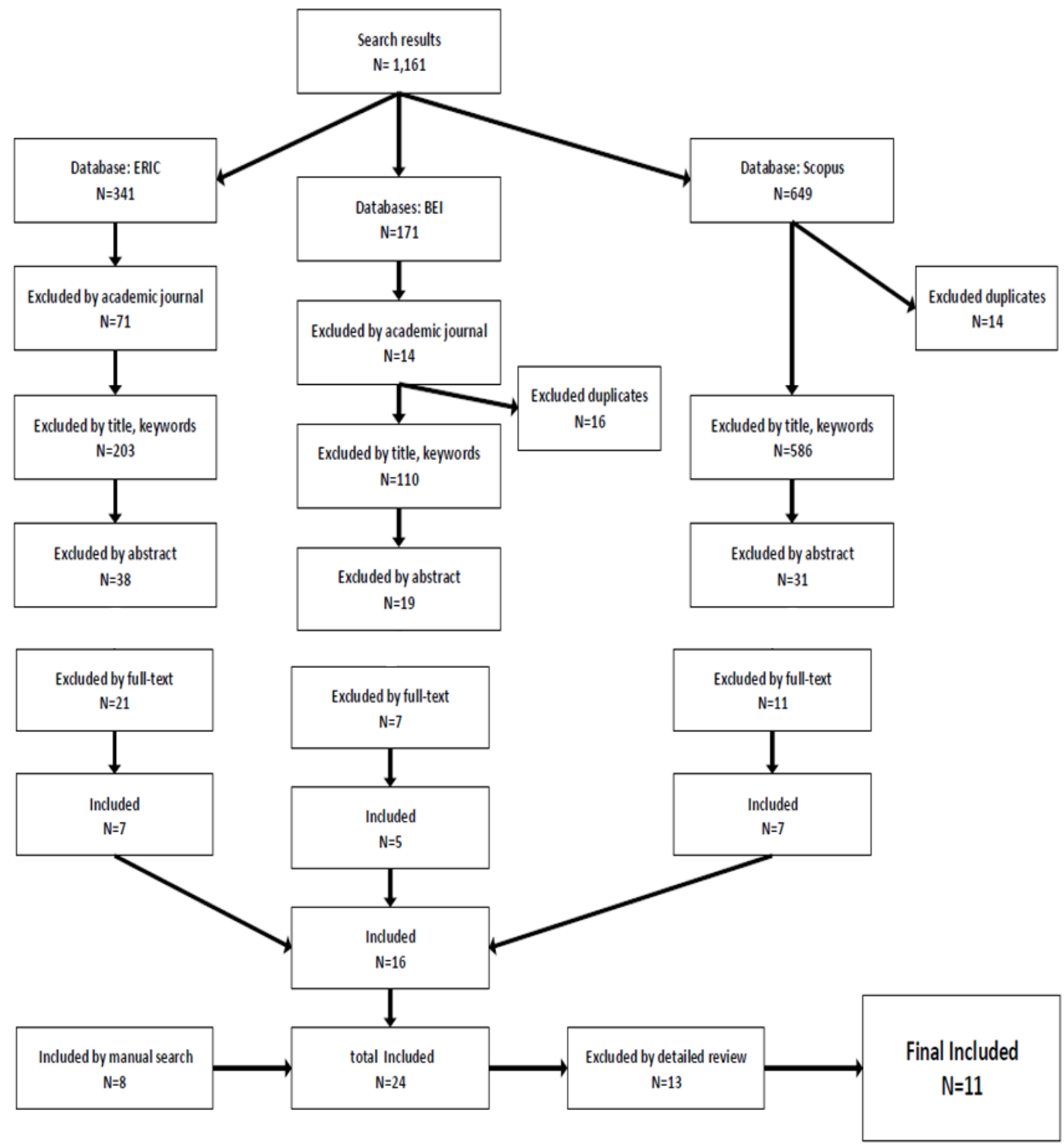

Table 1 Inclusion and exclusion criteria

\begin{tabular}{lll}
\hline & Inclusion & \\
\cline { 2 - 3 } 2 & Paper published in peer-reviewed journal & \\
& Paper published in English language & \\
& & 102
\end{tabular}

Exclusion

Paper not subject to peer-review

Paper published not in English language 
3 Paper published between 1990 to 2020

$4 \quad$ Study based on the UK context or regions within the UK

5 Study aims at children and young people aged from 10 to 19 years' old

6 Study has an analysis on both intimate relationship as well as addressing violence e.g. physical, psychological, sexual, controlling or cyber violence behaviours within an intimate relationships including dating relationships, sexual contact relationship or open relationship

$7 \quad$ Study evaluates any policy, intervention, or curriculum development in education field or within educational institution

8 Study includes qualitative methods e.g. interview, focus group, observation or case study
Paper published before the year of 1990

Study is not conducted within the UK context

Study aims at people under 10 years' old or over 19 years' old

Study focuses on intimate relationship without addressing violence

\section{e.g. teenage pregnancy}

Study focuses on addressing violence without discussing intimate partner relationship.

e.g. children maltreatment

Study does not include any policy or intervention

e.g. research about teenage mothers' experiences of IPV

Study includes policy or intervention but not within educational institution

e.g. treatment for sexual offenders

Study does not adopt qualitative methods

Table 2 Characteristics of included studies (Continued)

\begin{tabular}{|c|c|c|c|c|}
\hline $\begin{array}{l}\text { Name/type/locatio } \\
\mathrm{n} \text { of intervention }\end{array}$ & $\begin{array}{l}\text { Author(s)/year/typ } \\
\text { e of paper } \\
\text { (PR/GL) }\end{array}$ & $\begin{array}{l}\text { Details of } \\
\text { intervention }\end{array}$ & $\begin{array}{l}\text { Mentioned UK } \\
\text { policy/interventio } \\
\mathrm{n}\end{array}$ & $\begin{array}{l}\text { Summary of } \\
\text { the findings }\end{array}$ \\
\hline $\begin{array}{l}\text { Relationship } \\
\text { without fear (RwF) } \\
\text { Schools in the } \\
\text { area of the Stroke } \\
\text { on Trent and } \\
\text { Newcastle under } \\
\text { Lyme, England }\end{array}$ & $\begin{array}{l}\text { - Fox, Hale, and } \\
\text { Gadd (2014); PR } \\
\text { - Fox, Corr, Gadd, } \\
\text { and Sim (2016); } \\
\text { PR } \\
\text { - Fox and Gadd } \\
\text { (2012); GL } \\
\text { - Gadd, Fox, and } \\
\text { Hale (2014); PR }\end{array}$ & $\begin{array}{l}\text { Year: 2011- } \\
2012 \\
\text { Duration \& } \\
\text { delivery: } 6 \\
\text { weeks and 3- } \\
\text { month follow- } \\
\text { up; } 1 \text { hour per } \\
\text { week; deliver } \\
\text { during PSHE } \\
\text { lessons } \\
\text { Sample: } \\
\text { Students aged } \\
\text { from 8-16 } \\
\text { years' old }\end{array}$ & $\begin{array}{l}\text { Programmes } \\
\text { developed by } \\
\text { Women Aid, } \\
\text { Tender, the Zero } \\
\text { Tolerance Trust } \\
\text { or funded by } \\
\text { Home Office and } \\
\text { Children's Fund } \\
\text { initiatives } \\
\text { School } \\
\text { curriculum: RSE, } \\
\text { PSHE }\end{array}$ & $\begin{array}{l}\text { - What: this } \\
\text { intervention } \\
\text { focus on } \\
\text { attitude } \\
\text { change not } \\
\text { behaviours, } \\
\text { future studies } \\
\text { are needed to } \\
\text { see if attitudes } \\
\text { change can } \\
\text { transform into } \\
\text { behaviour } \\
\text { change, which } \\
\text { requires long- } \\
\text { term }\end{array}$ \\
\hline
\end{tabular}




\section{Methodology}

\& methods:

intervention

group, control

group, focus

group and

pre-test-post-

test

questionnaire

Themes:

primary

students on

peer

relationships;

secondary

students on

domestic

violence in

intimate

relationships,

including

attitudes to

domestic

violence,

experience of

abuse and

help seeking

skills intervention

e.g. 4 years'

follow-up;

measures are

needed to see

both

knowledge and

understanding

of different

forms of

violent

behaviours

and skills to

seek help

-Who: Avoid

being "sexist"

by focusing on

male

perpetrator

and female

victim;

consider

gender issues

in a more

thoughtful way;

teachers lack

expertise,

teacher

training is

critical; support

from specialist

expertise is

vital

-How:

Variability and

flexibility in

delivery

approach to

meet students'

preferences

and avoid 'one

size fit all';

whole school

approach or a

country-

approach is

recommended

to provide this 


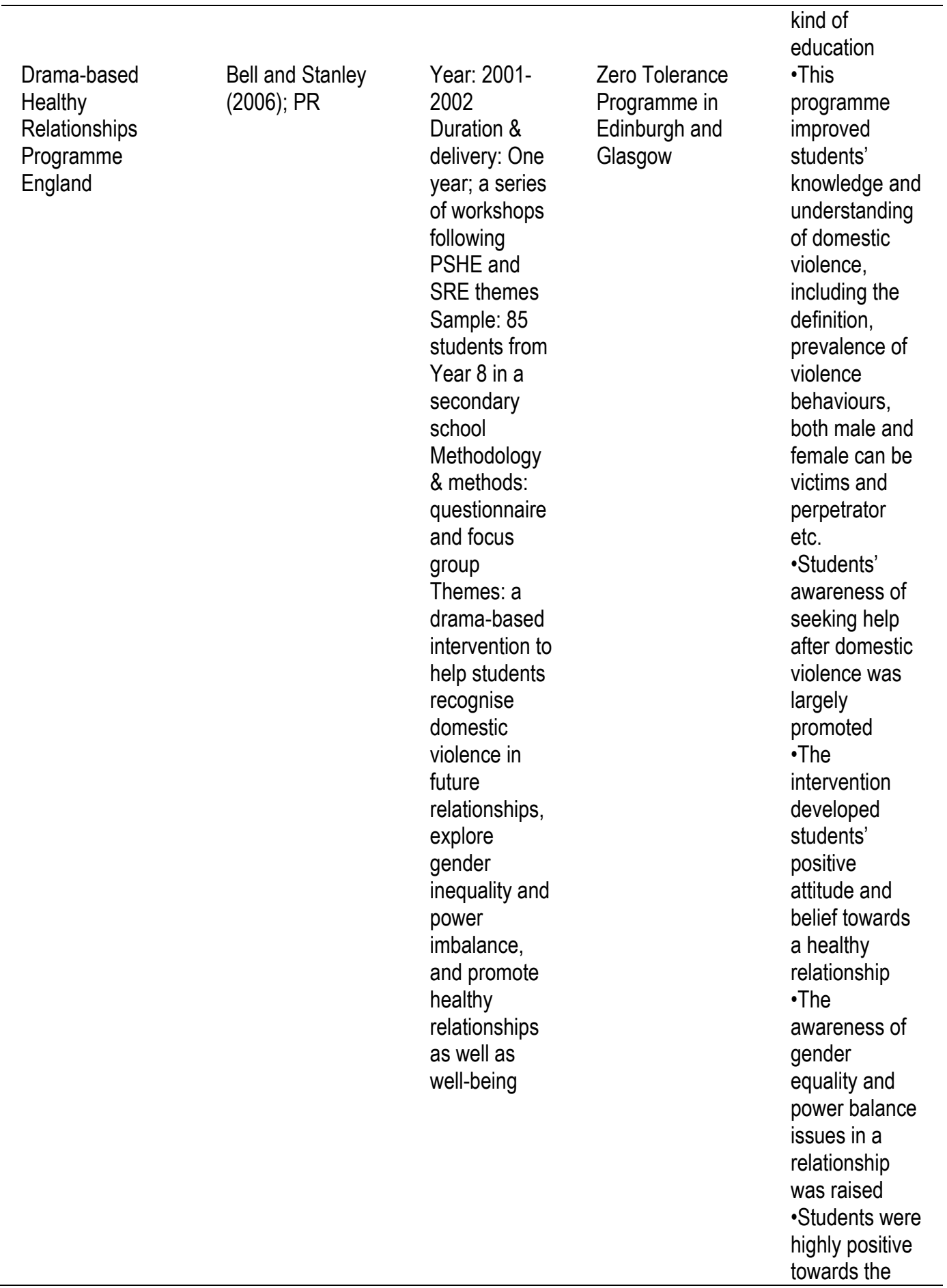




\begin{tabular}{|c|c|c|c|c|}
\hline & & & & $\begin{array}{l}\text { delivered } \\
\text { workshops }\end{array}$ \\
\hline $\begin{array}{l}\text { Tender Healthy } \\
\text { Relationships } \\
\text { project } \\
\text { Five regions in } \\
\text { England }\end{array}$ & $\begin{array}{l}\text { Sanders- } \\
\text { McDonagh, Apena } \\
\text { Rogers, Horvath, } \\
\text { and Selwood } \\
\text { (2015); GL } \\
\text { DMSS research } \\
\text { and consultancy } \\
\text { (2012); GL }\end{array}$ & $\begin{array}{l}\text { Year: 2012- } \\
2015 \\
\text { Duration \& } \\
\text { delivery: Over } \\
\text { a period of } 10 \\
\text { weeks } \\
\text { Sample: } \\
\text { students from } \\
\text { year } 9 \text { to 11; } \\
2050 \text { students } \\
\text { engaged in } \\
\text { workshops, } \\
\text { 15,404 } \\
\text { students } \\
\text { watched the } \\
\text { drama } \\
\text { Methodology } \\
\text { \& methods: } \\
\text { pre-post } \\
\text { questionnaire, } \\
\text { focus group, } \\
\text { semi- } \\
\text { structured } \\
\text { interview } \\
\text { Themes: } \\
\text { Drama based } \\
\text { project } \\
\text { encourage } \\
\text { students to } \\
\text { identify early } \\
\text { violence } \\
\text { behaviours; } \\
\text { provide } \\
\text { students with } \\
\text { further support } \\
\text { for future } \\
\text { relationships }\end{array}$ & $\begin{array}{l}\text { The Government } \\
\text { defines domestic } \\
\text { violence to } \\
\text { include } 16 \text { and } 17 \\
\text { years' old young } \\
\text { people } \\
\text { The STIR } \\
\text { (Safeguarding } \\
\text { Teenage Intimate } \\
\text { Relationship) } \\
\text { project carried } \\
\text { out in countries } \\
\text { including England } \\
\text { PSHE education } \\
\text { struggled to } \\
\text { include domestic } \\
\text { violence } \\
\text { prevention } \\
\text { Drama-based } \\
\text { Healthy } \\
\text { Relationship } \\
\text { Programme }\end{array}$ & $\begin{array}{l}\text {-Students } \\
\text { acquired an } \\
\text { improved } \\
\text { understanding } \\
\text { of the warning } \\
\text { of an } \\
\text { unhealthy } \\
\text { relationship } \\
\text { and obtained } \\
\text { the knowledge } \\
\text { to seek for } \\
\text { help and } \\
\text { support } \\
\text {-Workshops } \\
\text { were } \\
\text { effectively } \\
\text { delivered; the } \\
\text { impacts was } \\
\text { still continuing } \\
\text { after the } \\
\text { workshops had } \\
\text { concluded }\end{array}$ \\
\hline $\begin{array}{l}\text { The Zero } \\
\text { Tolerance } \\
\text { "Respect" Pilot } \\
\text { Project } \\
\text { Edinburg and } \\
\text { Glasgow }\end{array}$ & $\begin{array}{l}\text { Reid Howie } \\
\text { Associates } \\
\text { (2001);GL }\end{array}$ & $\begin{array}{l}\text { Year: } 2001 \\
\text { Duration \& } \\
\text { delivery: } 7-8 \\
\text { sessions } \\
\text { Sample: } \\
\text { young people } \\
\text { from } 2 \text { primary } \\
\text { schools, } 2\end{array}$ & $\mathrm{~N} / \mathrm{A}$ & $\begin{array}{l}\text {-The overall } \\
\text { views of the } \\
\text { intervention } \\
\text { are positive } \\
\text { and } \\
\text { supportive; it } \\
\text { helped } \\
\text { students to }\end{array}$ \\
\hline
\end{tabular}


secondary

schools and 7

youth groups

Methodology

\& methods:

interview,

questionnaire

and group

discussion

Themes:

promote

respectful and

equal

relationship,

encourage

healthy

relationship

among young

people and

educate them

with self-

respect,

respect for

other and

social

responsibilitie

$\mathrm{s}$

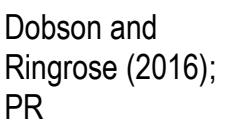

$\begin{array}{ll}\text { Year: N/A } & \text { Anti-sexting } \\ \text { Duration \& } & \text { content may be } \\ \text { delivery: the } & \text { taught through } \\ \text { film exposed } & \text { PSHE at schools } \\ \text { delivered } & \text { in England and } \\ \text { online and as } & \text { Wales } \\ \text { part of PSHE } & \\ \text { lesson plan } & \\ \text { Sample: the } & \\ \text { online study, } & \\ \text { 35 students } & \\ \text { aged 13-15 } & \\ \text { from two } & \\ \text { London } & \\ \text { schools } & \\ \text { engaged; the } & \end{array}$

promote

understanding

s about gender

stereotypes

and obtain

sources for

seeking help.

-Primary

prevention

work should

continue to

exist within

school

curriculum

framework

Avoid of being

anti-man when

design and

deliver the

sessions

- Timing is a

key issue in

terms of

lesson length

and delivering

Protection and

support should

be given to all

of those

involved in the

project

-Students

realised some

cyber sexual

violence

behaviours

through the

exposure

-Encourage

sexual

expression

emerged in

digital culture,

but should

consider

policy, ethics

and norm in 


\begin{tabular}{|c|c|c|c|c|}
\hline & & $\begin{array}{l}\text { follow-up } \\
\text { workshop } \\
\text { study, } 17 \\
\text { students } \\
\text { between } 14 \\
\text { and } 15 \text { from a } \\
\text { third school in } \\
\text { London } \\
\text { watched the } \\
\text { film } \\
\text { Methodology } \\
\text { \& methods: } \\
\text { focus group, } \\
\text { online } \\
\text { observation } \\
\text { and interview } \\
\text { Themes: A } \\
\text { film named } \\
\text { exposed has } \\
\text { been } \\
\text { produced as a } \\
\text { way to } \\
\text { educate } \\
\text { students with } \\
\text { the awareness } \\
\text { of sexting } \\
\text { abuse and } \\
\text { digital sexual } \\
\text { culture }\end{array}$ & & $\begin{array}{l}\text { the digital } \\
\text { world }\end{array}$ \\
\hline $\begin{array}{l}\text { Same-sex } \\
\text { relationship } \\
\text { education } \\
\text { the UK }\end{array}$ & $\begin{array}{l}\text { Donovan and } \\
\text { Hester (2008); PR }\end{array}$ & $\begin{array}{l}\text { Year: Jan } \\
\text { 2005-Dec } \\
2006 \\
\text { Duration \& } \\
\text { delivery: N/A } \\
\text { Sample: } \\
\text { young people } \\
\text { under aged } 25 \\
\text { years' old } \\
\text { Methodology } \\
\text { \& methods: } \\
\text { national wide } \\
\text { survey, four } \\
\text { focus group } \\
\text { with lesbians, } \\
\text { gay men, } \\
\text { heterosexual } \\
\text { women and } \\
\end{array}$ & $\begin{array}{l}\text { Sex and } \\
\text { Relationship } \\
\text { guidance (DfEE, } \\
\text { 2000)- the first } \\
\text { national work for } \\
\text { work in this field } \\
\text { Sex and } \\
\text { relationship } \\
\text { education locates } \\
\text { in the PSHE } \\
\text { curriculum }\end{array}$ & $\begin{array}{l}\text {-Abusive } \\
\text { behaviours in } \\
\text { same-sex } \\
\text { relationship } \\
\text { are overlooked } \\
\text { and minimised } \\
\text { Lack of } \\
\text { knowledge to } \\
\text { identify } \\
\text { abusive } \\
\text { relationship } \\
\text { and address it } \\
\text {-There is } \\
\text { limited places } \\
\text { in SRE to } \\
\text { educate } \\
\text { students with } \\
\text { avoiding }\end{array}$ \\
\hline
\end{tabular}




\begin{tabular}{|c|c|c|c|c|}
\hline & & $\begin{array}{l}\text { men, and } 67 \\
\text { interviews } \\
\text { Themes: } \\
\text { inclusion of } \\
\text { same-sex } \\
\text { relationship } \\
\text { and abuse to } \\
\text { SRE in } \\
\text { schools }\end{array}$ & & $\begin{array}{l}\text { same-sex } \\
\text { abusive } \\
\text { relationship } \\
\text { Sex education } \\
\text { and domestic } \\
\text { violence } \\
\text { prevention for } \\
\text { schools tend to } \\
\text { be } \\
\text { heterosexuality }\end{array}$ \\
\hline $\begin{array}{l}\text { 7. Sext education } \\
\text { The UK }\end{array}$ & $\begin{array}{l}\text { Jørgensen, } \\
\text { Weckesser, } \\
\text { Turner, and Wade } \\
\text { (2019); PR }\end{array}$ & $\begin{array}{l}\text { Year: } \\
\text { Nov2015- } \\
\text { Mar2016 } \\
\text { Duration \& } \\
\text { delivery: N/A } \\
\text { Sample: } 14 \\
\text { students aged } \\
\text { 13-15 } \\
\text { Methodology } \\
\text { \& methods: } \\
\text { Participatory } \\
\text { study, group } \\
\text { interview and } \\
\text { focus group } \\
\text { Themes: } \\
\text { young } \\
\text { people's views } \\
\text { on their own } \\
\text { support and } \\
\text { education } \\
\text { needs around } \\
\text { navigating the } \\
\text { phenomenon } \\
\text { of sexting }\end{array}$ & $\begin{array}{l}\text { Recommend sex } \\
\text { education as a } \\
\text { part of PSHE } \\
\text { curriculum }\end{array}$ & $\begin{array}{l}\text {-Sexting } \\
\text { education } \\
\text { needs to be } \\
\text { developed } \\
\text { within the } \\
\text { context of } \\
\text { wider } \\
\text { relationship } \\
\text { issues, such } \\
\text { as gender, } \\
\text { power } \\
\text { dynamics and } \\
\text { trust between } \\
\text { peers, and } \\
\text { improved } \\
\text { communication } \\
\text { between } \\
\text { students and } \\
\text { teachers or } \\
\text { other } \\
\text { responsible } \\
\text { adults } \\
\text { •Design and } \\
\text { communicate } \\
\text { messages } \\
\text { around sexting } \\
\text { to young } \\
\text { people within } \\
\text { and beyond } \\
\text { educational } \\
\text { settings }\end{array}$ \\
\hline
\end{tabular}

*PR= peer reviewed GL=grey literature $\mathrm{N} / \mathrm{A}=$ not available *Information above all derived from the included papers, data all provided by the author/authors 


\subsubsection{Results}

This study identified 11 school-based IPV studies, which were categorised into seven types of educational interventions. The first five educational interventions (see in Table 2) were conducted by external organisations identified in nine studies on addressing IPV issues among young people within school settings including: Relationship without fear $(n=4)$, Healthy Relationship Programme $(n=1)$, Tender's Healthy Relationship Education $(n=2)$, the Zero Tolerance "Respect" Pilot Project $(\mathrm{n}=1)$ and Think $\mathrm{U}$ Know Campaign $(\mathrm{n}=1)$. Among the five educational interventions, one was implemented in Scotland (the Zero Tolerance "Respect" Pilot Project) and the others were carried out in England. The latter two included studies (see Table 2) about students' view towards the existing PSHE and RSE curriculum and addressing newly emerged IPV issues within school curriculum including same-sex relationship education and sext education.

Among the included qualitative studies, majority of the research adopted interview and focus group as the methods for data collection. The sample of most studies are among young people from secondary schools aged 10 to 15 and in a group of less than 50 participants. Most of the studies did not mention the gender composition of the participants, while one study (same sex relationship education) looked into the gender differences of participants as lesbians, gay men, heterosexual women and men. Additionally, the relationship without fear (RwF) programme also provided a comparative analysis of attitudinal changes between male and female students before and after the intervention. Almost all studies were delivered with the theme to promote healthy and respectful relationships, generally during PSHE and RSE curriculum in a period of intervention less than half year.

Two government policies were highly emphasised in the articles reviewed: the government definition of domestic violence extend to include 16 to 17 young people and the guidance of sex and relationship education 2000 (Dobson \& Ringrose, 2016; Sanders-McDonagh et al., 2015). Besides, several interventions have been mentioned in the reviewed studies and undertaken by external organisations as Women aid, NSPCC and Tender. There were also some interventions that were supported by the UK government such as the Safeguarding Teenage Intimate Relationship (STIR) project, the Zero Tolerance "Respect" Pilot Project and Teenage Relationship Abuse Campaign (Fox et al., 2016; Sanders-McDonagh et al., 2015).

A summarised list of findings from all included papers is presented in the fourth column of Table 2. Three themes emerged following a thematic synthesis, which will be outlined in the next section.

\section{Findings and analysis}

To answer the proposed research questions, we undertook a comprehensive examination of the 'results' and 'findings' sections of the 11 included studies. All the selected papers were entered into the qualitative data analysis software Nvivo 12 pro 
to facilitate a systematic analysis. To ensure our analysis was rigorous, we adopted a three-stages thematic synthesis, pioneered by Thomas and Harden $(2008$, p. 4) as follows: 1) line-by-line text coding; 2) constructing descriptive themes; and 3) generating analytical themes. The authors argue that the process of descriptive and analytical themes interpretation can produce transparent and explicit outcomes (Thomas \& Harden, 2008). Three themes were generated as a result of conducting the thematic synthesis method

Impacts of the intervention

Evaluations of the intervention

Identified recommendations by the papers

\subsection{Impacts of the intervention}

\subsubsection{Attitudinal change}

The majority of the interventions indicate significant improvements in changing participants' attitudes including less acceptance of abusive and violent behaviours, increased awareness of gender equality in intimate relationships and enhanced knowledge level towards IPV (Bell \& Stanley, 2006; Fox et al., 2016; Fox et al., 2014; Gadd et al., 2014; Reid Howie Associates, 2001). Gadd et al. (2014) point out that the Rwf was effective in changing students' attitudes regarding the results of the comparison between students in the intervention group and the control group. Fox et al. (2016) concluded that both male and female students benefited from the intervention in changing attitude whereas male students' attitudinal change towards IPV after the intervention just achieved female students' attitude level before the intervention. Also, students who had the history of IPV reached the same level of attitudinal change with students who did not have IPV experience. Most of the studies witnessed reduction in the participants' acceptance level of IPV from before to after the intervention (Fox \& Gadd, 2012; Fox et al., 2014; Hale, Fox, \& Gadd, 2012). Considerable evidence shows that students' awareness of what constitutes a healthy relationship was highly enhanced as their responses of 'don't know' to questions were decreased mainly after the intervention (Bell \& Stanley, 2006; Reid Howie Associates, 2001; Sanders-McDonagh et al., 2015). Besides, students obtained a variety of knowledge regarding IPV including the definition of IPV, the early warnings of an unhealthy relationship, the prevalence of IPV, and an understanding of the fact both man and women can be victims and perpetrators of IPV (Bell \& Stanley, 2006; Sanders-McDonagh et al., 2015).

\subsubsection{Behavioural change - help seeking skills}

As for behavioural change, different interventions have different views on the effectiveness concerning altering behaviours. On the one hand, some studies found that students applied knowledge to realistic actions in combating IPV shortly after the intervention. For example, they started to talk about the harmfulness of IPV 
behaviours to family members and seek accessible sources for support (Bell \& Stanley, 2006; Jørgensen et al., 2019). When it comes to whom to turn to help, most participants prefer to contact professionals anonymously or report IPV behaviours to police rather than communicate with family, friends or teachers (Bell \& Stanley, 2006; Jørgensen et al., 2019). A boy participant in Bell and Stanley (2006, p. 242) mentioned that 'he would have taken the advice and phoned the national child helpline as he does not have to give his name or anything.' Moreover, a girl participant added that 'teachers will tell other staffs.' On the other hand, others argue that compared with changes in attitude, no persuasive evidence is available to show how the knowledge learned can be put into practice in a real-life situation (Fox et al., 2016; SandersMcDonagh et al., 2015). Only ask for participants' perceptions if they would seek help or whom they would turn to help cannot measure their realistic behaviours in help seeking in a real-life context (Fox et al., 2016). Therefore, longitudinal studies, e.g., up to one-year pre-test-post-test study or a 4-year follow-up period are needed to examine how knowledge obtained from the intervention can be translated into effective behaviours in the future.

\subsection{Evaluations of the intervention}

\subsubsection{Positive-like the intervention}

This review identified some positive comments from participants who took part in the intervention. Students expressed their affections towards the intervention as they benefited a lot from these interventions. For example, the majority of participants from Fox and Gadd (2012, p. 19) mentioned that 'all the RwF sessions were very good' and they 'enjoyed being part of it a lot'. Also, they learnt the characteristics of a healthy relationship, different types of IPV behaviours and how to get support in an abusive relationship. Additionally, Reid Howie Associates (2001) points out that the majority of the participants claimed to enjoy all the sessions, and none of them identified a session that was not enjoyable. However, Bell and Stanley (2006) argue that the intervention was more popular with girls, while boys showed less interest in them.

\subsubsection{Negative-dislike the intervention}

Some participants showed their unease and dislike at being part of these interventions. As mentioned in Fox et al. (2014), participants easily became bored and started to chat with others because there were too many lessons, case studies and stories. Similar to Jørgensen et al. (2019), which pointed out the whole school assemblies were ineffective in delivering the information as there was no one listening. Some students also felt awkward to role play in IPV situation, and students who watched role-play could feel uncomfortable as it aroused their own lived experience (Fox et al., 2014). Most of the students' reflected that 'we didn't enjoy the role-play' (Fox et al., 2014, p. 34). Additionally, some sexist comments also made male students feel upset because they were mainly blamed for abusive behaviours (Gadd et al., 2014). For example, concerns from the focus groups in Gadd et al. (2014, p. 474) 
indicated that 'male gender was getting blamed for abusive...' and 'there were boys also have problems with girls, maybe the ones who were victims'. Besides, some students were anxious about future relationships after the intervention and started to worry about getting into an abusive relationship.

\subsection{Identified recommendations by the papers}

\subsubsection{The content}

Few studies discussed the need to clarify what topics should be included to the content of interventions across the UK. There were several interventions conducted by institutions in the UK such as Tender, Women Aids and the Zero Tolerance Trust, however, all of them are different in the content they used (Fox et al., 2016). It was argued that future studies better to make a comparison between different interventions to decide what content should be adopted (Fox et al., 2016). Also, it is highlighted that the importance of catering to students' preference in designing the content. Students' active participation requires varied content to include a variety of actives (Fox et al., 2014). In addition, content on gender should be designed to attract different gender needs and delivered more thoughtfully, avoid being "sexist" by only focusing on male perpetrators, female victims or heterosexual relationships (Dobson \& Ringrose, 2016; Donovan \& Hester, 2008; Fox et al., 2014). Evidence shows that boy participants complained that 'it is always men beating women- it is sexist against men' (Fox et al., 2014, p. 35). Besides, there are recommendations to add content regarding violence in same-sex relationship and sexting violence as part of the PSHE curriculum (Donovan \& Hester, 2008; Jørgensen et al., 2019).

\subsubsection{The approach}

The majority of interventions are carried out in a small group within a short period. A country-wide approach still absent in the UK to make sure all students have the chance to receive IPV education (Fox et al., 2016). Besides, the long-term approach is highly demanded to capture the realistic impacts interventions have on students in the long run (Fox et al., 2016). Moreover, it is necessary to avoid 'one-size fits all' approach when delivering the content, teachers should respond to the needs of all students and student-centred approach works better to teacher-led approach for this type of education (Fox et al., 2014). As a participant argued that 'the lessons was not to do with us, we were just listening' (Fox et al., 2014, p. 33). Other participants also reflected that they have to find the information themselves instead of letting teachers tell them (Fox et al., 2014). Another point that needs considering more carefully is the gender approach in content delivery. This is important because gender understanding in teaching techniques can assist the intervention to be more inclusive and appeal to gender needs (Sanders-McDonagh et al., 2015). When it comes to measuring the effectiveness of interventions, various views were identified in the studies. Gadd et al. (2014) argue that there was a lack of measures in quite a few aspects of the possible changings in attitude, knowledge, understanding, empathy and help-seeking 
behaviours, whereas Reid Howie Associates (2001) points out that there was a need to bear the limitations in mind that an intervention cannot solve all these issues.

\section{Discussion}

To our knowledge, this is mong the first review to identify and evaluate the UK based policy and home-grown interventions on preventing IPV. The majority of the systematic reviews regarding school-based interventions were globally based (De Koker, Mathews, Zuch, Bastien, \& Mason-Jones, 2014; Parkes et al., 2016; Stanley, Ellis, Farrelly, Hollinghurst, \& Downe, 2015), and a large substantial number of the identified interventions were implemented in the US such as Safe Dates, Coaching Boys into Men and Dating Violence Prevention Project. Therefore, it is doubtful to what extent the interventions have been done in the US are transferable to inform the UK practice since social norms, beliefs and cultures are different between countries. Although this review identified one paper of UK based multi-agency approaches on preventing domestic violence, school's role was less valued in this paper since more emphasis given to policy, NHS and external charity organisations (Cleaver et al., 2019). Moreover, there is increasing attention from the UK educational policy and practice on tackling IPV issues among young people, and a growing number of IPV based interventions published in the UK. Therefore, it is the time to conduct a review to gather evidence on what UK have done to tackling IPV and what impacts these interventions have on addressing IPV issues.

In review, most of the included studies are educational programmes carried out by external organisations to promote young people's awareness of identifying the early signs of IPV and to educate them with the knowledge and skills in addressing IPV issues in relationships (Bell \& Stanley, 2006; Dobson \& Ringrose, 2016; Fox et al., 2016). These included studies either developed the curriculum (Fox et al., 2016; Fox et al., 2014; Reid Howie Associates, 2001), drama (Bell \& Stanley, 2006; DMSS research and consultancy, 2012) or film (Dobson \& Ringrose, 2016) as educational strategies to prevent IPV. However, the majority of existing preventive programmes are small scale, methodology limited, low dissemination of findings and have little evidence of effectiveness on the intervention outcomes. In contrast, Relationship without Fear (RwF) project is a well disseminated educational programme among the studies identified. There are three articles published in peer-reviewed journals about the RwF programme (Fox et al., 2016; Fox et al., 2014; Gadd et al., 2014). Articles present that RwF programme is a large scale intervention with about 1203 students from thirteen schools in England (Fox et al., 2016, p. 217). Distinct from other qualitative studies, which adopt the interview or focus group for data collection, $\mathrm{RwF}$ programme carried out a research with a pre-test-post-test design with a control group and then had a 3-month follow-up period for examining the ongoing outcomes. The findings show that RwF changed the attitude towards the acceptance of IPV and mitigated the risk of forming an abusive relationship among young people (Fox et al., 2016). However, the UK educational programme addressing IPV is still in its infancy 
stage. More studies are needed to bridge the research gap on the IPV intervention approach e.g., a country-wide study, longitudinal intervention, gender approach.

While there is still a concern about the effective delivery of RSE because of the teachers confidence and comfort level regarding the content (Bell \& Stanley, 2006; Donovan \& Hester, 2008; Reid Howie Associates, 2001), RSE curriculum will be made compulsory in all schools in the UK from 2020 (Long, 2018). Besides, teachers who hold gender stereotypes and have aggressive tendencies may project a confusing gender norm to students and fail to mitigate the risk of resorting violence among students. Therefore, support from RSE subject's specialists and professional training is critical in overcoming these challenges when teaching RSE curriculum. However, another concern is that there is no standard assessment for RSE and there is a need for the common understanding of the rationale and purpose of schools' achievement on RSE. Although levels, grades or pass/fail assessments are not suitable to RSE subjects, informal assessments through teachers' observation, verbal feedback and students' self-assessment should be adored (Formby et al., 2010; PSHE Association, 2020).

\section{Conclusion}

Educational interventions to prevent IPV is of critical importance but relatively underexplored in the UK and the work to address IPV issues is still in low profile within the formal school settings (Fox et al., 2014; Stanley, Ellis, Farrelly, Hollinghurst, \& Downe, 2015). This review identified 11 school-based IPV studies from peerreviewed journals and grey literature. The central theme of educational programmes is to reshape social norm toward gender inequality and stereotypes as well as to create respect and equal relationships (Bell \& Stanley, 2006). Generally, by promoting young people's awareness on identifying the early sign of IPV and educating them with the knowledge and skills in relation to IPV. However, the majority of existing preventive programmes are small scale, limited in their methodology, the dissemination of findings is low and have little evidence of effectiveness on the intervention outcomes.

This review locates the majority of studies from the UK grey literature while much fewer sources are available from peer-reviewed journals to inform what has been done to prevent IPV issues. Besides, there is still a research gap in eliminating IPV issues from monitory groups of people, including abusive same-sex relationship, IPV against women and girls from monitory communities, women perpetrate as well as men victims.

\section{Appendices}

\section{Appendix A. PICo framework}




\begin{tabular}{|c|c|c|c|c|c|}
\hline $\begin{array}{l}\text { Girl* OR } \\
\text { Female OR } \\
\text { Gender OR } \\
\text { Sex*OR } \\
\text { Student }^{*} \text { OR } \\
\text { Pupil* OR } \\
\text { Undergraduate* }\end{array}$ & $\begin{array}{l}\text { Polic* OR } \\
\text { Law* OR }^{*} \\
\text { Legislation } \\
\text { OR } \\
\text { Intervent* } \\
\text { OR } \\
\text { Prevent* OR } \\
\text { Protect* OR } \\
\text { Evaluat* OR } \\
\text { assess* OR } \\
\text { Program* } \\
\text { OR } \\
\text { Campaign* } \\
\text { OR } \\
\text { Project* }\end{array}$ & $\begin{array}{l}\text { Gender OR } \\
\text { Domestic OR } \\
\text { Intimate OR } \\
\text { Relationship } \\
\text { OR Dating }\end{array}$ & $\begin{array}{l}\text { Violen* } \\
\text { OR } \\
\text { Abus* OR } \\
\text { Aggress* } \\
\text { OR } \\
\text { Harass* }\end{array}$ & $\begin{array}{l}\text { School* OR } \\
\text { College OR } \\
\text { 'Six Form' } \\
\text { OR } \\
\text { Universit*' } \\
\text { OR } \\
\text { 'Higher } \\
\text { education' }\end{array}$ & $\begin{array}{l}\text { UK OR } \\
\text { 'United } \\
\text { Kingdom' } \\
\text { OR Britain } \\
\text { OR } \\
\text { England } \\
\text { OR } \\
\text { Wales OR } \\
\text { Scotland } \\
\text { OR } \\
\text { 'Northern } \\
\text { Ireland' }\end{array}$ \\
\hline
\end{tabular}

\section{Appendix B. Search terms}

\begin{tabular}{|c|c|}
\hline \multicolumn{2}{|c|}{ Search terms used in three databases } \\
\hline ERIC & 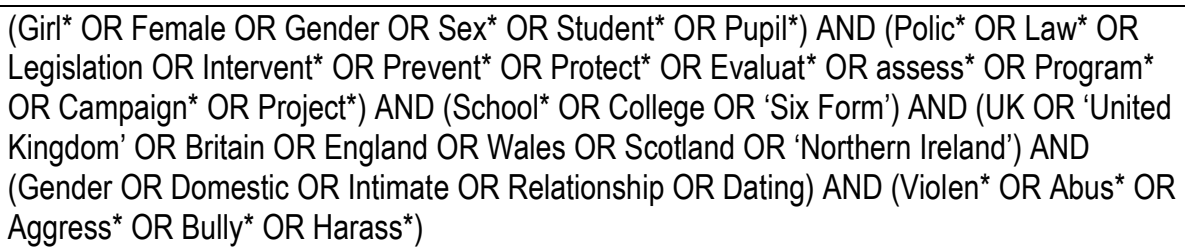 \\
\hline $\mathrm{BEI}$ & 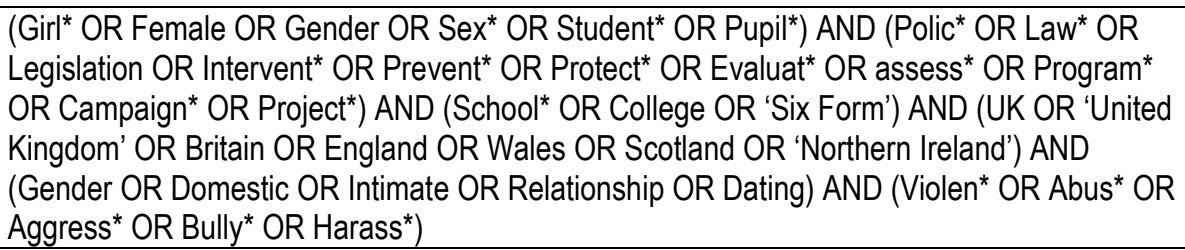 \\
\hline Scopus & $\begin{array}{l}\text { (girl* OR female OR gender OR sex* OR student* OR pupil* OR ) AND (polic* OR } \\
\text { law* OR legislation OR intervent* OR prevent* OR protect* OR evaluat* OR assess* } \\
\text { OR program* OR campaign* OR project*) AND ( school* OR college OR 'six form') } \\
\text { AND ( UK OR 'united AND kingdom' OR britain OR england OR wales OR scotland } \\
\text { OR 'northern AND ireland') AND ( gender OR domestic OR intimate OR relationship } \\
\text { OR dating ) AND ( violen* OR abus* OR aggress* OR bully* OR harass*) AND ( } \\
\text { limit-to ( doctype, "ar" )) AND ( limit-to ( subjarea, "soci" ) ) AND (limit-to ( language, } \\
\text { "English" ) ) AND ( limit-to ( srctype, "j" )) }\end{array}$ \\
\hline
\end{tabular}

\section{References}

[1] Barter, C., McCarry, M., Berridge, D., \& Evans, K. (2009). Partner exploitation and violence in teenage intimate relationships. NSPCC.

[2] Bell, J., \& Stanley, N. (2006). Learning about domestic violence: young people's responses to a healthy relationships programme. Sex Education, 6(3), 237-250. doi:10.1080/14681810600836356 
[3] Cleaver, K., Maras, P., Oram, C., \& McCallum, K. (2019). A review of UK based multi-agency approaches to early intervention in domestic abuse: lessons to be learnt from existing evaluation studies. Aggression and Violent Behavior, 46, 140-155. doi:10.1016/j.avb.2019.02.005

[4] Coy, M., \& Garner, M. (2012). Definitions, discourses and dilemmas: policy and academic engagement with the sexualisation of popular culture. Gender and Education, 24(3), 285-301. doi:10.1080/09540253.2012.667793

[5] De Koker, P., Mathews, C., Zuch, M., Bastien, S., \& Mason-Jones, A. J. (2014). A systematic review of interventions for preventing adolescent intimate partner violence. Journal of Adolescent Health, 54(1), 3-13.

[6] Department for Education. (2018). Relationships education, relationships and sex education (RSE) and health education: draft for consulation. London: Department for Education

[7] Department for Education. (2019). Draft statutory guidance: relationships education, relationships and sex education (RSE) and health education. London: Department for Education

[8] DMSS research and consultancy. (2012). Tender's healthy relationship education in schools funded by comic relief: final evaluation summary report. Retrieved from https://tender.org.uk/wpcontent/uploads/2016/05/Tender-final-evaluation-report-summaryversion-20-Sept-2012-DMSS.pdf

[9] Dobson, A. S., \& Ringrose, J. (2016). Sext education: pedagogies of sex, gender and shame in the schoolyards of "tagged" and "exposed". Sex Education: Sexuality, Society and Learning, 16(1), 8-21.

[10] Donovan, C., \& Hester, M. (2008). "Because she was my first girlfriend, I didn't know any different": making the case for mainstreaming same-sex sex and relationship education. Sex Education: Sexuality, Society and Learning, 8(3), 277-287.

[11] Fancy, K., \& Fraser, E. M. (2014). DFID guidance note on addressing violence against women and girls (VAWG) in education programmes - part A. London: VAWG helpdesk

[12] Formby, E., Coldwell, M., Stiell, B., Demack, S., Stevens, A., Shipton, L., ... Willis, B. (2010). Personal, Social, Health and Economic (PSHE) Education: A mapping study of the prevalent models of delivery and their effectiveness. The UK

[13] Fox, C., Corr, M. L., Gadd, D., \& Sim, J. (2016). Evaluating the effectiveness of domestic abuse prevention education: Are certain children more or less receptive to the messages conveyed? Journal of Legal Criminological Psychology, 21(1), 212-227.

[14] Fox, C., \& Gadd, D. (2012). REaDAPt: research report evaluation of three european schools-based domestic violence prevention education programmes. Retrieved from 
http://www.readapt.eu/sites/default/files/documents/First\%20Complete \%20Research\%20Report.pdf

[15] Fox, C., Hale, R., \& Gadd, D. (2014). Domestic abuse prevention education: listening to the views of young people. Sex Education: Sexuality, Society and Learning, 14(1), 28-41.

[16] Gadd, D., Fox, C. L., \& Hale, R. (2014). Preliminary steps towards a more preventative approach to eliminating violence against women in Europe. European Journal of Criminology, 11(4), 464-480.

[17] Gelles, R. (1980). Violence in the family: a review of research in the seventies. Journal of Marriage and the Family, 42(4), 873-885.

[18] Graca, S. (2017). Domestic violence policy and legislation in the UK: a discussion of immigrant women's vulnerabilities. European Journal of Current Legal Issues, 22(1).

[19] Hale, B., Fox, C., \& Gadd, D. (2012). Evaluation of three European schoolsbased domestic violence prevention education programmes.

[20] Home Office. (2013). A call to end violence against women and girls-action plan. London: HM Government

[21] Home Office. (2016). Ending Violence against Women and Girls Strategy 2016 - 2020. The UK

[22] Jørgensen, C. R., Weckesser, A., Turner, J., \& Wade, A. (2019). Young people's views on sexting education and support needs: findings and recommendations from a UK-based study. Journal of Sex Education, 19(1), $25-40$.

[23] Khadijah, F., \& McAslan, F. E. (2014). DIFD guidance note on addressing violence against women and girls (VAWG) in education programming. London: VAWG Helpdesk

[24] Long, R. (2018). Relationships and sex education in schools (England). House of Common

[25] Parkes, J., Heslop, J., Ross, F. J., Westerveld, R., \& Unterhalter, E. (2016). A rigorous review of global research evidence on policy and practice on school-related gender-based violence. UNICEF.

[26] Phipps, A., \& Smith, G. (2012). Violence against women students in the UK: time to take action. Gender and Education, 24(4), 357-373.

doi:10.1080/09540253.2011.628928

[27] PSHE Association. (2020). PSHE education programme of study key stages 1-5. Retrieved from the UK: https://www.psheassociation.org.uk/system/files/PSHE\%20Association\%20Programme $\% 2$ 0of\%20Study\%20for\%20PSHE\%20Education $\% 20 \% 28$ Key\%20stages $\% 20$ 1\%E2\%80\%935\%29\%2C\%20Jan\%202020_1.pdf

[28] Reid Howie Associates. (2001). Evaluation of the zero tolerance "respect" pilot project. Retrieved from

[29] Sanders-McDonagh, E., Apena Rogers, S., Horvath, M., \& Selwood, S. (2015). Evaluation report of the tender healthy relationships project national 
partnership programme. Retrieved from http://tender.org.uk/wpcontent/uploads/2016/05/Final-Evaluation-Report.-The-Tender-HealthyRelationship-Project.pdf

[30] Stanley, N., Ellis, J., Farrelly, N., Hollinghurst, S., Bailey, S., \& Downe, S. (2015). Preventing domestic abuse for children and young people (PEACH): a mixed knowledge scoping review. Public Health Research, 3(7).

[31] Stanley, N., Ellis, J., Farrelly, N., Hollinghurst, S., \& Downe, S. (2015). Preventing domestic abuse for children and young people: A review of school-based interventions. Children and Youth Services Review, 59, 120 131. doi:https://doi.org/10.1016/j.childyouth.2015.10.018

[32] Thomas, J., \& Harden, A. (2008). Methods for the thematic synthesis of qualitative research in systematic reviews. BMC Medical Research Methodology, 8(1), 45-45. doi:10.1186/1471-2288-8-45

[33] Young, H., Turney, C., White, J., Bonell, C., Lewis, R., \& Fletcher, A. (2017). Dating and relationship violence among 16-19 year olds in England and Wales: a cross-sectional study of victimization. Journal of Public Health, 19. 